\title{
Serological diagnosis of paracoccidioidomycosis in HIV-coinfected patients
}

\author{
Fernando Bellissimo-Rodrigues ${ }^{1}$, Lucia Helena Vitali, Roberto Martinez²/+ \\ 'Departamento de Medicina Social ²Departamento de Clínica Médica, Faculdade de Medicina de Ribeirão Preto, \\ Universidade de São Paulo, Av. Bandeirantes 3900, 14048-900 Ribeirão Preto, SP, Brasil
}

\begin{abstract}
Paracoccidioidomycosis should be differentiated from other opportunistic diseases in human immunodeficiency virus (HIV)/acquired immunodeficiency syndrome (AIDS) patients who live in Latin America. Laboratory investigation can begin with serological tests, which are rapid and efficient. In the present study, double immunodiffusion (DID), counterimmunoelectrophoresis (CIEP) and an enzyme linked immunosorbent assay (ELISA) tests were assessed for the detection of anti-Paracoccidioides brasiliensis antibodies in 40 patients coinfected with HIV. The results were compared to those obtained for 75 non-HIV-infected patients with endemic paracoccidioidomycosis. Anti-P. brasiliensis antibodies were detected in 65\% (DID), 79\% (CIEP) and 95\% (ELISA) of the patients with HIV/ AIDS, significantly lower rates than those detected in cases of endemic paracoccidioidomycosis, which were $89 \%$, $99 \%$ and $100 \%$, respectively. The reactive sera of HIV-infected patients also showed lower anti-P. brasiliensis antibody titres than those of non-HIV-infected patients. Despite the lower intensity of the specific humoral response, serological tests are useful for the diagnosis of opportunistic paracoccidioidomycosis in the HIV/AIDS population. We suggest optimization of the laboratory diagnosis by combining the ELISA test with CIEP or DID.
\end{abstract}

Key words: paracoccidioidomycosis - HIV - AIDS - double immunodiffusion - ELISA - counterimmunoelectrophoresis

In a vast area of South America, paracoccidioidomycosis is the fourth most common systemic fungal infection among patients with human immunodeficiency virus (HIV)/acquired immunodeficiency syndrome (AIDS). Opportunistic infection with Paracoccidioides brasiliensis is generally disseminated among patients with a low CD4 cell count, involving the lungs, tegument, lymph nodes, monocyte-macrophage system and other tissues (Silva-Vergara et al. 2003, Morejón et al. 2009). This clinical picture must be differentiated from other opportunistic infections, particularly those involving mycobacteria and histoplasmosis.

The detection of serum anti- $P$. brasiliensis antibodies is a rapid, non-invasive and efficient method for the laboratory diagnosis of endemic paracoccidioidomycosis not associated with HIV/AIDS. The recommended serological tests are double immunodiffusion (DID), counterimmunoelectrophoresis (CIEP) and enzyme linked immunosorbent assay (ELISA) (Shikanai-Yasuda et al. 2006). With the use of appropriate antigens and procedures, these tests reach a sensitivity of $90 \%$ or more and high specificity (Mendes-Giannini et al. 1994). The titration of anti-P. brasiliensis antibodies is important for the laboratory diagnosis and follow up of paracoccidioidomycosis. Patients with active disease usually have high antibody levels, which decline with antifungal therapy and clinical recovery (Del Negro et al. 2000).

Financial support: UPDT/PN-DST /AIDS/MS

+ Corresponding author: rmartine@fmrp.usp.br

Received 30 April 2010

Accepted 27 July 2010
Immunosuppressed patients with opportunistic paracoccidioidomycosis may have a reduced specific humoral immune response. A significant proportion of false-negative results of serological tests for the detection of antibodies against $P$. brasiliensis have been observed in patients with AIDS-associated paracoccidioidomycosis (Marques et al. 2000). Few cases of this coinfection have been reported and they are distributed among various medical services with no uniformity regarding the serological tests (Goldani \& Sugar 1995). Thus, the objective of the present study was to compare the performance of DID, CIEP and ELISA for the serological diagnosis of paracoccidioidomycosis in patients infected with HIV. Serum samples from patients with endemic paracoccidioidomycosis and not infected with HIV were subjected to the same tests and the results obtained were used as reference for the habitual serological response to this fungal disease.

\section{PATIENTS, MATERIALS AND METHODS}

Patients and serum samples - The serological tests were applied to serum samples from 40 patients coinfected with P. brasiliensis and HIV and from 75 patients with endemic paracoccidioidomycosis not infected with HIV. The diagnosis of paracoccidioidomycosis was based on the observation of the fungus in a mycological or histopathological exam and/or on the isolation of $P$. brasiliensis in culture. Blood samples were collected before the beginning of antifungal treatment and the sera were stored at $20^{\circ} \mathrm{C}$. Blood samples were collected from 1991-2008 for both patient groups.

The patients with opportunistic paracoccidioidomycosis and coinfected with HIV were 16-57 years old (median $=32$ years old) and the man:woman ratio was $4: 1$ and 25 out of 33 patients $(75.8 \%)$ had CD4 cell counts $<200$ cells $/ \mu \mathrm{L}$. The disease was limited to the lungs, oral mucosa and upper airways in seven patients and 33 patients had disseminated 
lesions particularly involving the lungs, skin and lymph nodes, commonly associated with hepatosplenomegaly. HIV infection was determined by laboratory tests such as ELISA HIV $1 / 2^{\circledR}$ (Abbott Laboratories, Abbott Park, USA), particle agglutination (Serodia HIV ${ }^{\circledR}$, Fujirebio, Inc) and western blot for anti-HIV antibodies (Genelabs Diagnostics, Singapore).

The 75 patients with endemic paracoccidioidomycosis and not infected with HIV were 17-74 years old (median $=48$ years old), with a man:woman ratio of 11.5:1.0. The acute/subacute form of paracoccidioidomycosis affected 16 out of 75 subjects $(21.3 \%)$, while 59 out of $75(78.7 \%)$ had the chronic form, according to the accepted classification of the disease (Franco et al. 1987).

Gel DID - The DID test was carried out on glass plates covered with agarose gel $\left(\right.$ Sigma $\left.^{\mathbb{Q}}\right)$ punched with a metal mould to form a central well and six peripheral ones. The central well was filled with a pool of exoantigens from eight $P$. brasiliensis clinical isolates (RP 61, RP 68, RP 73, RP 74, RP 76, RP 79, RP 86 and RP 89). The exoantigens were prepared by dialysis and concentration of the liquid medium of $P$. brasiliensis mycelial cultures. The exoantigen pool had a protein content of $1.84 \mathrm{mg} / \mathrm{mL}$. Patient serum and its dilutions in $0.9 \%$ saline were placed in the peripheral wells. The plates were incubated for $72 \mathrm{~h}$ and then immersed in $0.9 \%$ saline for $24 \mathrm{~h}$. After drying, the gel was stained with Coomassie brilliant blue $\left(\right.$ Sigma $\left.^{\circledR}\right)$. The highest dilution that still formed a precipitate band was considered to be the antibody titre of the serum.

CIEP - CIEP was carried out on $8 \times 10 \mathrm{~cm}$ glass plates covered with type II agarose gel $\left(\right.$ Sigma $\left.^{\circledR}\right)$ diluted in sodium barbital buffer $\left(\operatorname{Merck}^{\circledR}\right), \mathrm{pH}$ 8.2. Two parallel rows of wells punched in the gel respectively received the antigen and serial serum dilutions in $0.9 \%$ saline. The antigen was obtained from yeasts of six P. brasiliensis isolates $(\mathrm{Pb} 339$, $\mathrm{Pb}$ 18, BOAS, BAT, RP 51 and RP 54). The cells were ruptured by ultrasound sonication and the antigenic pool had a protein concentration of $4.07 \mathrm{mg} / \mathrm{mL}$. The plates were subjected to a 30-mAmp electric current for $60 \mathrm{~min}$ and then immersed in $0.9 \%$ saline for $24 \mathrm{~h}$. After drying, the gel was stained with Coomassie brilliant blue $\left(\operatorname{Sigma}^{\mathbb{Q}}\right)$. The serum antibody titre was considered to be the highest dilution that formed immune precipitate bands with the antigen.

ELISA - Polystyrene plates (Immulon ${ }^{\circledR}$, Dynatech Laboratories, USA) were sensitized with $200 \mu \mathrm{L} /$ well of a pool of exoantigens from eight $P$. brasiliensis clinical isolates (RP 65, RP 68, RP 69, RP 73, RP 75, RP 76, RP 86 and RP 91) after dilution with carbonate-bicarbonate buffer and overnight incubation at $4^{\circ} \mathrm{C}$. The exoantigen pool was prepared as described for DID and had a protein concentration of $1.36 \mathrm{mg} / \mathrm{mL}$. After the initial step and before the addition of other reagents, the plates were washed three times with phosphate buffered saline containing $0.05 \%$ Tween 20 (PBS-T). Unbound sites were blocked with 4\% bovine albumin $\left(\right.$ Sigma $\left.^{\circledR}\right)$ and the plates received $\geq 1: 200$ serum dilutions in PBS-T. After incubation at $37^{\circ} \mathrm{C}$ for $60 \mathrm{~min}$, peroxidase-conjugated goat anti-human IgG (Sig$\mathrm{ma}^{\circledR}$ ) was added. The immunological reaction was revealed with o-phenylenediamine dihydrochloride $\left(\operatorname{Sigma}^{\circledR}\right)$ and absorbance at $492 \mathrm{~nm}$ was measured with a Multiskan ${ }^{\circledR}$ plate reader (Lab Systems). The cut-off was determined as the serum absorbance of healthy individuals plus two standard deviations. The antibody titre of paracoccidioidomycosis sera corresponded to the highest dilution at which absorbance remained higher than the cut-off.

Statistical analysis - Data were analyzed statistically by the Chi-square test and Fisher test (rate of reacting sera) and also by the Mann-Whitney test with normal approximation (comparison of serological titres).

\section{RESULTS}

In both groups of patients, ELISA showed the highest positivity, followed by CIEP and DID. The proportion of patients with anti-P. brasiliensis antibodies detected

TABLE

Anti-Paracoccidioides brasiliensis antibodies determined by double immunodiffusion (DID), counterimmunoelectrophoresis (CIEP) and enzyme linked immunosorbent assay (ELISA) tests in patients with paracoccidioidomycosis and infected with human immunodeficiency virus (HIV+) or not infected (HIV-)

\begin{tabular}{|c|c|c|c|c|c|c|}
\hline & \multicolumn{2}{|c|}{ DID } & \multicolumn{2}{|c|}{ CIEP } & \multicolumn{2}{|c|}{ ELISA } \\
\hline & HIV+ & HIV- & HIV+ & HIV- & HIV+ & HIV- \\
\hline Patients $n$ & 40 & 75 & 40 & 75 & 40 & 75 \\
\hline Test positivity ${ }^{a} \%$ & 65 & 89 & 77.5 & 98.7 & 95 & 100 \\
\hline $\begin{array}{l}\text { Titer range }^{b} \\
\text { (minimum/maximum) }\end{array}$ & NR/1024 & NR/2048 & NR/8192 & $\mathrm{NR} / 62536$ & NR/204800 & $1600 / 204800$ \\
\hline $\operatorname{Titer}^{b}$, mean $\pm \mathrm{SD}$ & $121 \pm 273$ & $272 \pm 451$ & $507 \pm 1329$ & $1439 \pm 7550$ & $15910 \pm 35255$ & $45376 \pm 60138$ \\
\hline Median titer $^{b}$ & 12 & 64 & 96 & 256 & 4800 & 25600 \\
\hline $\mathrm{p}^{c}$ & \multicolumn{2}{|c|}{$<0.001$} & \multicolumn{2}{|c|}{$<0.05$} & \multicolumn{2}{|c|}{$<0.0001$} \\
\hline
\end{tabular}

$a$ : number of positive samples/total number of samples x 100; $b$ : inverse of the titer expressed as dilution of the serum sample; $c$ : comparison of the titers of each serological test between HIV-coinfected and non-coinfected patients (Mann-Whitney test); NR: non-reactive; SD: standard deviation. 


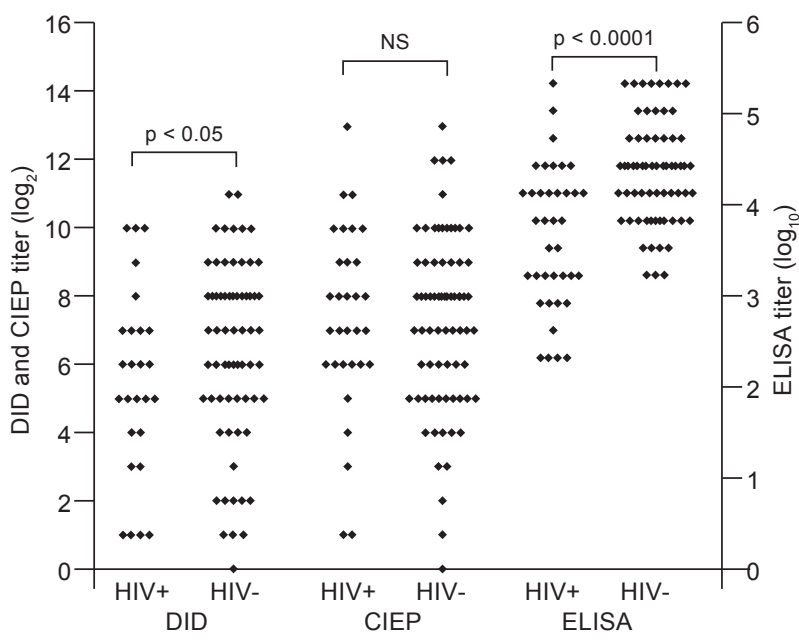

Anti-Paracoccidioides brasiliensis antibody titers in reactive sera of patients with paracoccidioidomycosis and infected with human immunodeficiency virus (HIV+) or not infected (HIV-) in three tests: double immunodiffusion (DID), counterimmunoelectrophoresis (CIEP) and enzyme linked immunosorbent assay (ELISA). Non-reactive sera were excluded. NS: non-significant $(p>0.05)$.

in serum was lower among HIV-infected subjects than among those with endemic paracoccidioidomycosis. The difference was more marked in the DID (65\% vs. $89 \%$, p $<0.01)$ and CIEP $(77.5 \%$ vs. $98.7 \%, \mathrm{p}<0.05)$ tests than in ELISA (95\% vs. $100 \%, \mathrm{p}>0.05)$ (Table). In all three serological tests, the antibody titres were significantly lower among HIV/AIDS patients (Table). Even when nonreactive sera were excluded, HIV/AIDS patients had lower anti-P. brasiliensis antibody titres in the DID and ELISA tests than patients with endemic paracoccidioidomycosis (Figure).

\section{DISCUSSION}

The present study shows that patients with HIV/AIDS coinfected with $P$. brasiliensis have a weaker humoral response against the fungus than patients with endemic paracoccidioidomycosis. It was also demonstrated that the detection of anti- $P$. brasiliensis antibodies can be enhanced with the use of more sensitive tests than DID.

The rate of positivity for serum anti- $P$. brasiliensis antibodies detected in patients with endemic paracoccidioidomycosis was comparable to the sensitivity observed in other studies, i.e., $65-100 \%$ for DID, $77-97 \%$ for CIEP and $66-100 \%$ for ELISA (Mendes-Giannini et al. 1994, Bueno et al. 1997, Do Valle et al. 2001). Falsenegative results for specific antibodies may occur in patients not infected with HIV, especially those with the chronic form of the disease and an unifocal, small lesion (Del Negro et al. 2000). Patients with this form of paracoccidioidomycosis have a less intense humoral immunological response than patients with acute/subacute form of the disease (Panunto-Castelo et al. 2003).

In patients with paracoccidioidomycosis associated with HIV/AIDS, false-negative serological tests for anti- $P$. brasiliensis antibodies were more common, cor- responding to $1 / 3$ of the samples in DID. In a series of coinfected patients in which a small number of patients were assessed with serological tests for anti- $P$. brasiliensis antibodies, false-negative results were obtained in 33\% (Paniago et al. 2005) and 66\% (Marques et al. 1995) of the serum samples. The use of CIEP or ELISA increased the rate of reactive sera; however, in both tests the low levels of anti- $P$. brasiliensis in some HIV-infected patients were insufficient for a safe serological diagnosis of paracoccidioidomycosis because of cross-reactions and specificity lower than 100\% (de Camargo 2008). In this investigation, the joint use of two serological tests increased to $100 \%$ the positivity of detection of $P$. brasiliensis antibodies (data not shown). Thus, the serological diagnosis of paracoccidioidomycosis in patients with HIV/AIDS is improved by using ELISA in combination with DID or CIEP. Alternatively, the detection of circulating fungal antigens can lead to a diagnosis of paracoccidioidomycosis in AIDS patients (Gómez et al. 1998).

The partial failure of the humoral immune response against $P$. brasiliensis in HIV-infected patients was also demonstrated by the lower antibody titres compared to patients with endemic paracoccidioidomycosis. This failure has been attributed to B cell dysfunction due to HIV infection (Benard \& Duarte 2000), which also impairs the humoral response in opportunistic histoplasmosis (Kauffman 2008), coccidioidomycosis (Singh et al. 1996) and aspergillosis (Martinez et al. 2009). Surprisingly, some patients with severe cell immunodeficiency respond with high antibody titres, as observed in the present study and in previous reports (Tobon et al. 1998). There may be other causes contributing to a lower level of anti- $P$. brasiliensis antibodies, such as the more rapid progression of paracoccidioidomycosis in patients infected with HIV (Morejón et al. 2009). Moreover, in these patients, fungal disease may be the consequence of reactivation of residual foci of the primary infection that arose in the remote past, a condition in which there may be a reduced stimulus for antibody production.

Despite their low sensitivity in detecting anti- $P$. brasiliensis antibodies, serological tests have been useful in endemic areas for the differentiation between paracoccidioidomycosis and other opportunistic infections in patients with HIV/AIDS. In these cases, it is recommendable to use at least two serological tests and to determine the titre of anti- $P$. brasiliensis antibodies to improve the performance of this method of laboratory diagnosis.

\section{REFERENCES}

Benard G, Duarte AJ 2000. Paracoccidioidomycosis: a model for evaluation of the effects of human immunodeficiency virus infection on the natural history of endemic tropical diseases. Clin Infect Dis 31: 1032-1039.

Bueno JP, Mendes-Giannini MJ, Del Negro GM, Assis CM, Takiguti CK, Shikanai-Yasuda MA 1997. IgG, IgM and IgA antibody response for the diagnosis and follow-up of paracoccidioidomycosis: comparison of counterimmunoelectrophoresis and complement fixation. J Med Vet Mycol 35: 213-217.

de Camargo ZP 2008. Serology of paracoccidioidomycosis. Mycopathologia 165: 289-302.

Del Negro GM, Pereira CN, Andrade HF, Palacios SA, Vidal MM, Charbel CE, Benard G 2000. Evaluation of tests for antibody re- 
sponse in the follow-up of patients with acute and chronic forms of paracoccidioidomycosis. J Med Microbiol 49: 37-46.

Do Valle AC, Costa RL, Fialho Monteiro PC, Von Helder J, Muniz MM, Zancopé-Oliveira RM 2001. Interpretation and clinical correlation of serological tests in paracoccidioidomycosis. Med Mycol 39: 373-377.

Franco M, Montenegro MR, Mendes RP, Marques SA, Dillon NL, Mota NG 1987. Paracoccidioidomycosis: a recently proposed classification of its clinical forms. Rev Soc Bras Med Trop 20: 129-132.

Goldani LZ, Sugar AM 1995. Paracoccidioidomycosis and AIDS: an overview. Clin Infect Dis 21: 1275-1281.

Gómez BL, Figueroa JI, Hamilton AJ, Diez S, Rojas M, Tobón AM, Hay RJ, Restrepo A 1998. Antigenemia in patients with paracoccidioidomycosis: detection of the 87-kilodalton determinant during and after antifungal therapy. J Clin Microbiol 36: 3309-3316.

Kauffman CA 2008. Diagnosis of histoplasmosis in immunosuppressed patients. Curr Opin Infect Dis 21: 421-425.

Marques SA, Conterno LO, Sgarbi LP, Villagra AM, Sabongi VP, Bagatin E, Gonçalves VL 1995. Paracoccidioidomycosis associated with acquired immunodeficiency syndrome. Report of seven cases. Rev Inst Med Trop Sao Paulo 37: 261-265.

Marques SA, Robles AM, Tortorano AM, Tuculet MA, Negroni R, Mendes RP 2000. Mycoses associated with AIDS in the Third World. Med Mycol 38 (Suppl. 1): 269-279.

Martinez R, Castro G, Machado AA, Moya MJ 2009. Primary aspergilloma and subacute invasive aspergillosis in two AIDS patients. Rev Inst Med Trop Sao Paulo 51: 49-52.
Mendes-Giannini MJS, Del Negro GB, Siqueira AM 1994. Serodiagnosis. In M Franco, CS Lacaz, A Restrepo-Moreno, G Del Negro (eds.), Paracoccidioidomycosis, CRC Press, Boca Raton, p. 345-363.

Morejón KM, Machado AA, Martinez R 2009. Paracoccidioidomycosis in patients infected with and not infected with human immunodeficiency virus: a case-control study. Am J Trop Med Hyg 80: $359-366$

Paniago AM, de Freitas AC, Aguiar ES, Aguiar JI, da Cunha RV, Castro AR, Wanke B 2005. Paracoccidioidomycosis in patients with human immunodeficiency virus: review of 12 cases observed in an endemic region in Brazil. J Infect 51: 248-252.

Panunto-Castelo A, Freitas-da-Silva G, Bragheto IC, Martinez R, Roque-Barreira MC 2003. Paracoccidioides brasiliensis exoantigens: recognition by IgG from patients with different clinical forms of paracoccidioidomycosis. Microbes Infect 5: 1205-1211.

Shikanai-Yasuda MA, Telles Filho FQ, Mendes RP, Colombo AL, Moretti ML 2006. Consenso em paracoccidioidomicose. Rev Soc Bras Med Trop 39: 297-310.

Silva-Vergara ML, Teixeira AC, Curi VG, Costa Júnior JC, Vanunce R, Carmo WM, Silva MR 2003. Paracoccidioidomycosis associated with human immunodeficiency virus infection. Report of 10 cases. Med Mycol 41: 259-263.

Singh VR, Smith DK, Lawrence J, Kelly PC, Thomas AR, Spitz B, Sarosi GA 1996. Coccidioidomycosis in patients infected with human immunodeficiency virus: review of 91 cases at a single institution. Clin Infect Dis 23: 563-568.

Tobon AM, Orozco B, Estrada S, Jaramillo E, de Bedout C, Arango M, Restrepo A 1998. Paracoccidioidomycosis and AIDS: report of the first two Colombian cases. Rev Inst Med Trop Sao Paulo 40: $377-381$ 